Website: https://hipotenusa.iainsalatiga.ac.id/index.php/hipotenusa/index

Dafid Slamet Setiana, Nuryadi, Rusgianto Heri Santoso

\title{
The Correlation between Reasoning and Emotional Intelligence in Social Interaction to Mathematics Achievement
}

\author{
*Dafid Slamet Setiana ${ }^{1}$, Nuryadi ${ }^{2}$, Rusgianto Heri Santoso ${ }^{3}$ \\ ${ }^{1,3}$ Pendidikan Matematika, Universitas Sarjanawiyata Tamansiswa, Indonesia. \\ ${ }^{2}$ Pendidikan Matematika, Universitas Mercu Buana Yogyakarta, Indonesia. \\ E-mail: dafid.setiana@ustjogja.ac.id ${ }^{1}$, nuryadi@mercubuana-yogya.ac.id ${ }^{2}$, \\ rusgianto@ustjogja.ac.id ${ }^{3}$ \\ *Correspoding Author \\ DOI: https://doi.org/10.18326/hipotenusa.v2i1.21-25
}

Submission Track:

Received : 09-04-2020

Final Revision : 15-06-2020

Available onlie : 17-06-2020

\begin{abstract}
Abstrak
Tujuan dari penelitian ini adalah untuk mengetahui hubungan antara penalaran dan kecerdasan emosional dalam interaksi sosial dengan prestasi belajar matematika. Penelitian ini merupakan penelitian eksperimental semu. Penelitian ini dilakukan di SMP 5 Yogyakarta, Indonesia dengan 90 responden yang dipilih secara acak. Penelitian ini memverifikasi hipotesis menggunakan metode survei dengan pendekatan teknik korelasi dan regresi. Penelitian ini melibatkan 3 (tiga) variabel, yaitu; prestasi matematika sebagai variabel dependen, dan dua variabel lain sebagai variabel independen. Variabel tersebut adalah penalaran dan kecerdasan emosional dalam interaksi sosial. Studi ini menemukan bahwa ada korelasi positif antara: (a) penalaran dan prestasi matematika; (b) kecerdasan emosional dalam interaksi sosial dan prestasi matematika; dan (c) ada korelasi positif antara penalaran dan kecerdasan emosional dalam interaksi sosial dengan prestasi matematika Studi ini diharapkan dapat sebagai pijakan untuk mengembangkan prestasi matematika melalui penalaran siswa, mengembangkan prestasi matematika melalui kecerdasan emosional dalam interaksi social, dan mengembangkan prestasi matematika melalui penalaran dan kecerdasan emosional dalam interaksi sosial.
\end{abstract}

Kata Kunci: Hubungan, Penalaran, Kecerdasan Emosional, Prestasi Matematika

\begin{abstract}
The objective of the research was to determine the correlation between reasoning, and emotional intelligence in social interaction to mathematics achievement. The research was conducted at SMP 5 Yogyakarta, Indonesia with 90 respondents who were selected by random sampling. The research verified the hypothesis used a survey method with correlation and regression technique approach. The research involved 3 (three) variables such as; mathematics achievement as the dependent variable and two other variables as the independent variables. They were reasoning and emotional intelligence in social interaction. The study found that there was a positive correlation between (a) reasoning and mathematics achievement; $(b)$ emotional intelligence in social interaction and mathematics achievement; and (c) there was a positive correlation between reasoning and emotional intelligence in the social interaction to mathematics achievement. This study is expected to be a consideration for developing mathematical achievement through student reasoning, developing mathematical achievement through emotional intelligence in social interactions, and developing mathematical achievement through reasoning and emotional intelligence in social interactions.
\end{abstract}

Keywords: Correlation, Reasoning, Emotional Intelligence, Mathematics Achievement 


\section{PENDAHULUAN}

Matematika adalah salah satu mata pelajaran yang diajarkan di sekolah. Matematika diajarkan dari sekolah dasar bahkan dari taman kanak-kanak atau kelompok bermain (non formal) hingga sekolah menengah. Tujuan umum pemberian matematika di sekolah yang terkait dengan isi kurikulum (Depdiknas, 2006) adalah: (1) untuk mempersiapkan siswa agar dapat menghadapi kondisi yang dapat berubah dalam kehidupan ini dan di dunia yang dinamis ini dengan mengambil tindakan berdasarkan pemikiran mereka secara logis, rasional, kritis, tepat, benar, efisien, dan efektif; (2) untuk mempersiapkan siswa untuk dapat menggunakan matematika dan membuat mereka berpikir pola matematis dalam kehidupan seharihari mereka dan untuk belajar berbagai pengetahuan. Hasil matematika pada Ujian Nasional dapat diketahui dari pencapaian nilai pada jenjang Sekolah Menengah Pertama (SMP). Hasilnya belum memuaskan dari tahun ke tahun. Berdasarkan laporan tahunan Departemen Pendidikan Nasional pada tahun 2015 hingga 2017, rata-rata skor yang diperoleh UN untuk Matematika di tingkat sekolah menengah pertama secara nasional belum pernah mencapai 60 (Fizriyani, 2016; Kemdikbud, 2017). Skor UN yang diperoleh di bawah 60 harus ditemukan penyebabnya dan harus diselesaikan.

Penguasaan matematika di Indonesia diajarkan di sekolah secara formal. Materi matematika diajarkan kepada siswa sekolah dasar dan menengah. Materi pembelajaran matematika dikembangkan dengan konsep berkelanjutan secara sistematis, sehingga siswa mudah mempelajarinya. Faktanya, ada banyak siswa yang memandang matematika secara negatif, para siswa menilai bahwa matematika adalah pelajaran yang sulit untuk dipelajari. Dan tentu saja, pandangan negatif siswa tentang matematika tersebut mempengaruhi pemikiran dan gaya belajar matematika siswa. Hal tersebut berdampak pada rendahnya kompetensi dan indikator penalaran siswa. Selanjutnya hal tersebut dapat menyebabkan rendahnya prestasi siswa dalam matematika.

Penalaran adalah organisasi yang melibatkan proporsi yang sesuai untuk menarik kesimpulan apa pun (Atkinson et al., 1999). Menurut Ball dan Bass (2003) penalaran adalah keterampilan dasar matematika yang diperlukan untuk sejumlah tujuan untuk memahami konsepkonsep matematika, untuk menggunakan ide-ide dan prosedur matematika secara fleksibel, dan untuk merekonstruksi teori tetapi tidak melupakan pengetahuan matematika itu sendiri. Berpikir adalah aktivitas manusia. Berpikir tidak dapat diamati, yang dapat diamati hanyalah produk dari pemikiran (Semiawan et. Al., 1999).

Penalaran dan pemecahan masalah adalah dua topik yang saling terkait satu sama lain yang menyebabkan orang harus berpikir. Fokus penalaran adalah bagaimana seseorang membuat kesimpulan dan mengevaluasi validasinya. Ada dua macam penalaran, yaitu penalaran deduktif dan induktif. Penalaran deduktif adalah proses penalaran dari satu atau lebih pernyataan (premis) untuk mencapai kesimpulan logis tertentu (Sternberg, 2009).

Kecerdasan emosional/Emotional Intelligence (EI) adalah kemampuan seseorang untuk mengenali emosi mereka sendiri dan emosi orang lain. Kecerdasan emosional membedakan antara perasaan yang berbeda dan memberi label dengan tepat, menggunakan informasi emosional untuk memandu cara berpikir dan perilaku, dan untuk mengelola dan/atau menyesuaikan emosi mereka untuk beradaptasi dengan lingkungan untuk mencapai tujuan seseorang (Andrew, 2008). Goleman (1996), kecerdasan emosional adalah kemampuan seseorang untuk memiliki motivasi diri dan bertahan dari kondisi frustrasi, untuk mengendalikan kebahagiaan yang berlebihan, dan untuk mengelola suasana hati atau kondisi jantung, seperti stres, empatik dan sebagainya. Kecerdasan Emosional (EI) adalah kemampuan untuk memonitor emosi seseorang dan orang lain dan untuk menggunakan informasi tersebut untuk memandu pemikiran dan tindakan (Salovey dan Mayer, 1990). Ukuran kinerja EI telah terkait dengan interaksi sosial, manajemen stres, kinerja akademik secara keseluruhan, dan komunikasi yang efektif (Brackett dan Mayer, 2003; Brackett et al., 2004; Mayer et al., 2004).

Interaksi sosial adalah proses dasar dari dua orang atau lebih untuk menggunakan bahasa atau sinyal untuk mempengaruhi setiap cara berpikir, harapan dan perilaku orang lain. Setiap orang harus memiliki kecerdasan emosional untuk berinteraksi satu sama lain. Kecerdasan emosional tersebut adalah: a) empati, b) keterampilan sosial, dan c) koordinasi sosial (Goleman, 1996). 
Prestasi matematika diraih oleh siswa melalui kerja keras dan tekun dalam belajar. Mereka belajar dengan kontrol emosi yang baik yang menunjukkan kecerdasan tinggi mereka. Penggunaan cara berpikir tertentu, sudah sesuai dengan kemampuan penalarannya. Para siswa yang menggunakan cara yang benar dalam belajar matematika, mereka akan mendapatkan prestasi matematika yang tinggi. Kecerdasan emosional dalam interaksi sosial, keterampilan siswa berinteraksi dengan teman-teman mereka, dan hubungan koordinasi interaksi dalam pembelajaran matematika di kelas adalah persyaratan bagi siswa untuk mencapai keberhasilan dalam pembelajaran matematika. Prestasi matematika siswa dapat dilihat dari hasil belajar siswa. Keberhasilan dalam kecerdasan emosional interaksi sosial. Akan lebih baik jika siswa memiliki kecerdasan emosi yang tinggi dalam interaksi sosial. Ini berarti bahwa kecerdasan emosional siswa yang lebih baik dalam interaksi sosial akan lebih baik dalam prestasi matematika, dan sebaliknya kecerdasan emosi siswa yang lebih rendah dalam interaksi sosial akan lebih rendah dalam prestasi matematika.

Banyak penelitian yang fokus membahas prestasi matematika (Beaton et al., 1996; Ding \& Davison, 2005; Lee, 2006; Marsh, 1986). Studi-studi ini menyimpulkan bahwa belajar adalah suatu proses yang dapat ditingkatkan dari waktu ke waktu dan bahwa prestasi matematika juga dapat meningkat.

Berdasarkan keerangka teori konseptual yang diuraikan di atas, diketahui bahwa ada korelasi di antara variabel-variabel seperti, penalaran, kecerdasan emosional siswa dalam interaksi sosial, dan prestasi matematika. Variabel penalaran dan kecerdasan emosional tersebut dapat dikatakan memiliki korelasi positif secara simultan terhadap prestasi belajar matematika.

Banyak upaya yang dilakukan oleh para guru, sekolah, dan juga oleh para ahli pendidikan matematika untuk mengurangi tingkat kompetensi penalaran siswa yang rendah. Bahkan, saat ini para pakar pendidikan matematika telah memberikan respon positif terhadap upaya peningkatan pendidikan matematika melalui Pendidikan Matematika Realistis (RME) atau Contextual Teaching and Learning (CTL). Sistem CTL adalah proses pendidikan yang bertujuan untuk membantu siswa melihat makna materi akademik yang telah mereka pelajari dengan cara menghubungkan materi pelajaran dengan konteks kehidupan sehari-hari mereka, seperti konteks keadaan pribadi, sosial, dan budaya mereka (Johnson, 2002). Definisi lain, pengajaran dan pembelajaran kontekstual adalah pendekatan pembelajaran yang tidak dapat dipisahkan dengan teori behaviorisme dan konstruktivisme. CTL adalah konsep pengajaran dan pembelajaran yang membantu guru menghubungkan materi pelajaran dengan situasi dunia nyata dan penerapannya dalam kehidupan mereka, seperti; keluarga, warga negara, dan pekerja (Hudson \& Whistler, 2007).

Menurut Suryanto (2000), tindakan mengacu pada pandangan fundamental yang mengklaim bahwa matematika harus relevan dengan kenyataan, dekat dengan pikiran siswa, dan relevan dengan masyarakat untuk nilai kemanusiaan. Proses pengembangan siswa membutuhkan perhatian dari guru dalam merencanakan dan mengelola proses belajar. Juga diperlukan perhatian terhadap kecerdasan emosional siswa dalam interaksi sosial sebagai salah satu ekspresi komunikasi antar siswa di kelas. Berdasarkan penjelasan di atas, perlu dilakukan penelitian berkaitan dengan penalaran, dan kecerdasan emosional dalam interaksi sosial dan hubungannya dengan prestasi matematika siswa.

\section{METODE}

Penelitian merupakan penelitian eksperimental semu. Penelitian ini dilakukan di SMP 5 Yogyakarta, Indonesia. Penelitian memverifikasi hipotesis menggunakan metode survei dengan pendekatan teknik korelasi dan regresi. Survei adalah penelitian yang mengambil sampel dari populasi tertentu dan menggunakan tes atau kuesioner sebagai sarana untuk mengumpulkan data dasar. Metode survei dapat digunakan untuk menguji hipotesis yang memiliki korelasi antara variabel terikat dan variabel bebas. Oleh karena itu, metode yang dipilih di sini adalah dengan melakukan survei. Seperti yang dijelaskan sebelumnya, penelitian ini melibatkan 3 (tiga) variabel yaitu; prestasi matematika sebagai variabel terikat, dan dua variabel lain sebagai variabel bebas, yaitu penalaran dan kecerdasan emosional dalam interaksi sosial. Banyak sampel yang digunakan yaitu 90 responden yang dipilih dengan menggunakan teknik random sampling. 
Penelitian ini menggunakan 3 (tiga) macam instrumen. Instrumen tersebut yaitu: (1) tes untuk mengukur prestasi matematika, (2) tes untuk mengukur penalaran, dan (3) kuesioner untuk mengukur kecerdasan emosional dalam interaksi sosial. Pertama instrumen penelitian disusun berdasarkan teori dan konseptual untuk kemudian diujicobakan kepada 40 responden. Berdasarkan item yang valid, nilai reliabilitas masing-masing instrumen adalah sebagai berikut: (1) tes untuk mengukur prestasi matematika adalah $0,76,(2)$ tes untuk mengukur penalaran adalah 0,72 , (3) dan, kuesioner untuk mengukur kecerdasan emosi dalam interaksi sosial adalah 0,80 .

\section{HASIL DAN PEMBAHASAN (70\%)}

Pertama, ada korelasi positif antara penalaran $\left(X_{1}\right)$ dan prestasi matematika $(Y)$ yang dinyatakan dalam persamaan regresi $\hat{Y}=$ $11,69+0,57 X_{1}$. Itu berarti bahwa setiap perubahan dalam satu skor penalaran akan meningkatkan nilai $\hat{Y}$ sekitar 0,57 dari standar konstanta 11,69. Hasil uji signifikan dan linieritas terhadap persamaan regresi menggunakan analisis varian. Koefisien korelasi sederhana adalah $r_{y 1}=0,32$. Hasil tersebut diuji menggunakan uji-t, dan hasilnya menunjukkan bahwa $t_{h}=4,06>t_{t}=2,39$ pada taraf signifikansi 0,01 .

Penalaran $\left(X_{1}\right)$ memiliki korelasi positif dengan prestasi belajar matematika $(Y)$ meskipun ada kontrol terhadap variabel independen lainnya, baik secara individu maupun simultan. Hal ini menunjukkan bahwa penalaran $\left(X_{1}\right)$ secara konsisten memiliki korelasi langsung dengan prestasi belajar matematika $(Y)$. Dengan demikian berarti bahwa siswa yang memiliki tingkat penalaran yang baik akan mendapatkan hasil yang baik pula dalam prestasi matematika mereka. Pernyataan tersebut juga didukung oleh penelitian lain, bahwa kinerja penalaran bersyarat berkorelasi dengan kemampuan matematika (Frosch \& Simms, 2015).

Kedua, ada korelasi positif antara kecerdasan emosional dalam interaksi sosial $\left(X_{2}\right)$ dan prestasi matematika $(Y)$ yang dinyatakan dalam persamaan regresi $\hat{Y}=$ $5,67+0,26 X_{2}$. Hal ini menunjukkan bahwa setiap perubahan dalam satu skor kecerdasan emosional dalam interaksi sosial akan meningkatkan nilai $\hat{Y}$ untuk sekitar 0,26 dari standar konstanta 5,67. Hasil uji signifikansi dan linearitas dari persamaan regresi menggunakan analisis varian. Koefisien korelasi sederhana $r_{y 3}=0,35$. Hasil tersebut diuji dengan menggunakan uji-t, dan hasilnya menunjukkan bahwa $t_{h}=4,33>t_{\text {tabel }}=$ 2,39 pada taraf signifikansi 0,01.

Kecerdasan emosional dalam interaksi sosial $\left(X_{2}\right)$ memiliki korelasi positif dengan prestasi belajar matematika $(Y)$, meskipun ada kontrol terhadap variabel independen lainnya, baik secara individu maupun simultan. Ini menunjukkan bahwa kecerdasan emosional dalam interaksi sosial $\left(X_{2}\right)$ secara konsisten memiliki korelasi langsung dengan prestasi belajar matematika. Itu berarti bahwa kecerdasan emosional yang lebih tinggi dalam interaksi sosial siswa akan berdampak pada nilai yang lebih tinggi dari prestasi matematika mereka. Penelitian lain yang dilakukan Awai dan Akosubo (2016), menunjukkan bahwa kecerdasan emosional memainkan peran penting dalam prestasi akademik siswa dalam matematika. Erasmus (2013) juga menyimpulkan bahwa kecerdasan emosional dapat berkontribusi pada berfungsinya peserta didik secara umum, serta untuk meningkatkan prestasi matematika.

Ketiga, ada korelasi positif antara penalaran $\left(X_{1}\right)$, dan kecerdasan emosional dalam interaksi sosial $\left(X_{2}\right)$, dan prestasi matematika $(Y)$ yang dinyatakan dalam persamaan regresi: $\hat{Y}=2,54+0,30 X_{1}+0,17 X_{2}$. Berdasarkan persamaan tersebut berarti bahwa setiap perubahan dalam satu skor penalaran, dan kecerdasan emosional dalam interaksi sosial akan meningkatkan nilai $\hat{Y}$ sekitar 0,30+ $0,17=0,43$ dari standar konstanta 2,54. Koefisien korelasi berganda dari $R=R_{y .12}=$ 0,432 . Hasil tersebut diuji menggunakan uji-F dan hasilnya menunjukkan bahwa $F_{\text {absolute }}=$ $10,28>t_{\text {tabel }}=4,04$ pada taraf signifikansi 0,01 . Singkatnya, hasil tes menunjukkan korelasi yang kuat antara prestasi matematika $(Y)$ dengan penalaran $\left(X_{1}\right)$ dan kecerdasan emosional dalam interaksi sosial $\left(X_{2}\right)$ secara bersamaan sangat signifikan.

Penalaran $\left(X_{1}\right)$ dan kecerdasan emosional dalam interaksi sosial $\left(X_{2}\right)$ secara bersamaan memiliki korelasi positif dengan prestasi belajar matematika $(Y)$. Berdasarkan temuan penelitian, dapat disimpulkan bahwa prestasi matematika siswa akan meningkat dengan meningkatkan penalaran siswa dan meningkatkan kecerdasan 
emosional mereka dalam interaksi sosial, baik secara individu maupun simultan. Secara ordinal, kontribusi variabel independen terhadap variabel dependen dari yang terbesar ke yang terkecil adalah variabel penalaran $\left(X_{1}\right)$ dan variabel kecerdasan emosional dalam interaksi $\operatorname{sosial}\left(X_{2}\right)$

\section{SIMPULAN}

Berdasarkan hasil penelitian, dapat diperoleh simpulan yaitu: (1) Penalaran memiliki korelasi positif dengan prestasi belajar matematika; (2) kecerdasan emosional dalam interaksi sosial memiliki korelasi positif dengan prestasi belajar matematika; (3) Penalaran dan kecerdasan emosional dalam interaksi sosial secara bersamaan memiliki korelasi positif dengan prestasi belajar matematika.

Berdasarkan hasil korelasi dan regresi penelitian yang dibahas, dapat dirumuskan beberapa implikasi. Hasil penelitian menyatakan bahwa ada korelasi positif antara variabel independen dan variabel dependen baik secara individu maupun simultan. Hal itu dimaksudkan agar untuk meningkatkan hasil pr4restasi matematika, diperlukan upaya dalam meningkatkan penalaran dan kecerdasan emosional dalam interaksi sosial.

\section{DAFTAR PUSTAKA}

Andrew (2008). A Dictionary of Psychology (3 ed.). Oxford University Press.

Awai, D. \& Akosubo, E. (2016). Emotional Intelligence and Self Concept as Predictors of Students' Academic Achievement in Mathematics. International Journal of Sciences: Basic and Applied Research (IJSBAR), 29(3), 233-231.

Ball DL, Bass H. (2003). Making mathematics reasonable in school. In: Kilpatrick J, Martin WG, Schifter DE (eds) A research companion to principles and standards for school mathematics. National Council of Teachers of Mathematics, Reston, VA, pp $27-44$

Beaton, A. E., Mullis, I. V. S., Martin, M. O., Gonzalez, E. J., Kelly, D. L., \& Smith, T. A. (1996). Mathematical achievement in the middle school years: IEA's third international mathematics and science study (TIMSS). Chestnut Hill, MA: Boston College, TIMSS International Study Center.

Brackett, M.A., Mayer, J.D. (2003). Convergent, discriminant, and incremental validity of competing measures of emotional intelligence. Personal. Soc. Psychol. Bull, 29, 1147-1158.

Brackett, M.A., Mayer, J.D.,Warner, R.M. (2004). Emotional intelligence and its relation to everyday behaviour. Pers. Individ. Differ, 36 (6), 1387-1402.

Depdiknas. (2006). Kurikulum Tingkat SatuanPendidikan. Jakarta: Depdiknas

Ding, C. S., \& Davison, M. L. (2005). A longitudinal study of math achievement gains of low achieving students. Contemporary Educational Psychology, 30(1), 81-95.

Erasmus (2013). Relationship between emotional intelligence, study orientation in maths and maths achievement of middle adolescent boys and girls. GSE Journal Of Education 2013, 12-21.

Fizriyani, W. (10 Juni 2016). Nilai Matematika Paling Turun pada UN 2016. Republika, hlm 1 .

Frosch, C. \& Simms, V. (2015) Understanding the role of reasoning ability in mathematical achievement. Research Gate, 633-638.

Goleman, D. (1996). Emotional Intelligence. New York: Bantam Books.

Hudson,C.C., \& Whisler, V. R. (2007). Contextual Teaching and Learning for Practitioners. Valdosta. Adult and Career Education of Vadolsta State University.

Johnson, E.B. 2002. Contextual Teaching and Learning: What It is and Why It is Here to Stay. Thousands Oaks, California: Corwin Press, Inc.

Kemdikbud. (2017). Konferensi Pers UN 2017 Jenjang SMP.

Lee, J. (2006). Tracking achievement gaps and assessing the impact of NCLB on the gaps: An in-depth look into national and state reading and math outcome trends. Cambridge, MA: The Civil Rights Project at Harvard University. 
Jurnal Hipotenusa, 2 (1), Juni 2020

Dafid Slamet Setiana, Nuryadi, Rusgianto Heri Santoso

Marsh, H. W. (1986).Verbal and math selfconcepts: An internal and external reference model. American Educational Research Journal, 23(1), 129- 149.

Mayer, J.D., Salovey, P., Caruso, D.R. (2004). Emotional intelligence: theory, findings, and implications. Psychol. Inq, 15 (3),

Salovey, P., Mayer, J.D., (1990). Emotional intelligence. Imagin. Cogn. Pers. 9, 185211.

Semiawan, Conny R.; Putrawan, I Made; Setiawan, I, Th. (1999). Dimensi Kreatif Dalam Filsafat Ilmu. Bandung: Remaja Rosdakarya.
Sternberg, R. J. (2009). Cognitive Psychology. Belmont, CA: Wadsworth.

Sudjana. (1983). Teknik Analisis Regresi dan Korelasi. Bandung: Tarsito.

Sudjana. Metoda Statistika. (1996). Bandung: Tarsito.

Suryanto.(2001).Pendidikan Matematika Realistik. Yogyakarta: Departemen Pendidikan Nasional Direktorat Jendral Pendidikan Dasar dan Menengah Pusat Pengembangan Pendidikan Guru (PPPG) Matematika. 